\title{
Effects of plant latex based anti-termite formulations on Indian white termite Odontotermes obesus (Isoptera: Odontotermitidae) in sub-tropical high infestation areas
}

\author{
Ravi Kant Upadhyay \\ D. D. U. Gorakhpur University, Gorakhpur, India; rkupadhya@yahoo.com \\ Received 24 July 2013; revised 24 August 2013; accepted 15 September 2013 \\ Copyright (C) 2013 Ravi Kant Upadhyay. This is an open access article distributed under the Creative Commons Attribution License, \\ which permits unrestricted use, distribution, and reproduction in any medium, provided the original work is properly cited.
}

\section{ABSTRACT}

In the present investigation various bioassays were conducted to evaluate the anti-termite efficacy of plant latex based formulations to control population of Indian white termite in subtropical soil. Results reveal that crude latex, its fractions and combinatorial fractions have shown very high toxicity against 0 . obesus. The $L_{50}$ values for different latex fractions of $24 \mathrm{~h}$ were in a range of $5.0-17.613 \mu \mathrm{g} / \mathrm{mg}$ while combined mixtures of Calotropis procera have shown synergistic activity against termites and caused comparably high mortality with LD $_{50}$ 1.987 - $6.016 \mu \mathrm{g} / \mathrm{mg}$. The mortality rate was found dose and time dependent as it was found to be increased with an increase in dose and exposure period. In olfactometry tests, C. procera latex solvent fractions have shown significant repellency at a very low dose $0.010-0.320$ $\mu \mathrm{g} / \mathrm{mg}$. Interestingly, solvent fractions have significantly repelled large numbers of worker termites due to volatile action of active components of latex and different additives. $E D_{50}$ values obtained in crude latex were $0.121 \mu \mathrm{g} / \mathrm{mg}$ body weights while combinatorial formulations have shown $E D_{50}$ in between $0.015-0.036 \mu \mathrm{g} / \mathrm{mg}$. Statistical analysis of repelled and un-repelled termites gave a low Chi-square value $\left(X^{2}\right.$ value $=$ 0.890 ) which is an indicator of independence of repellent action in randomly selected termite groups. In field experiments pre-soaked cotton threads impregnated with Calotropis procera crude latex were tagged around tree trunks of Tectona grandis provided a wider protection against $O$. obesus. By employing these pre-coa- ted threads, termite infestation and tunneling activity were significantly decreased ( $p<0.05$ and 0.01). When germinating crop plants were sprayed with various plant latex formulations, these have caused very high protective efficacy against termite infestation. It has significantly reduced crop losses up to $6.45 \%$. There was a significant difference in infestation obtained in control and treatment groups ( $P<0.05$ and 0.01$)$ which shows that Calotropis procera possesses enough anti-termite potential against Indian white termite, 0 . obesus population. If used these, formulations may also provide wide a range of control against other kinds of pests including house hold, medical and veterinary. However, Calotropis procera latex based formulations can be recommended for effective control of termites in high infestation areas by applying spray, or in form of poison baits or as fumigant in pure form.

Keywords: Calotropis procera; Odontotermes obesus; Plant Latex; Toxic Effects

\section{INTRODUCTION}

Termites are highly destructive polyphagous insect pests of crop plants, which damage green foliages, seedlings, wood, fibers, and other household cellulose based materials. Most of the termite species attack crop plants, significantly reduce yield and heavily infest post harvest stored products. Most of field termites live in huge mounds, invade green vegetation and dry biomass. Both worker and soldier termites harm non-seasoned commercial wood and its formed materials. Whether it is a rural area or an urban domestic site, termite menace is every- 
where. In forests, gardens and even in houses termites make tunnels, adjoin them with green biomass, vegetation, or crop fields. However, for controlling termite population and its menace in the field, various synthetic pesticides such as chlorodane [1], cypermethrin [2], hydroquinone and indoxcarb [3] have been used. Due to their longer residual persistence in the environment, these were proved highly toxic to non-target organisms in the ecosystem. Hence, new alternatives of synthetic pesticides were discovered in form of natural pesticides which display low toxicity to humans and the environment, having low costs among other advantages [4].

Plant latex is a complex mixture of proteins, alkaloids, starch, sugars, oils, tannins, resins, and gums [5]. It is a natural plant polymer secreted by highly specialized cells known as laticifers [6]. It shows deleterious effects like toxic, antifeedant, growth and reproductive inhibitory in number of insect species [7]. Latex bearing plant species from Annonaceae, Solanaceae Asteraceae, Cladophoraceae, Labiatae, Meliaceae, Oocystaceae and Rutaceae possess diverse phytochemicals having very high insecticidal potential against crop [8-10] and medical pests, i.e. Culex quinquefasciatus [11], Sarcophaga haemorrhoidalis [12] and Musca domestica [13]. Latex of C. procera also affects gonotrophic cycles of Aedes aegypti [14] and prevents egg hatching and larval development [15]. Hence, after observing its toxic nature to a number of insects including termites [16,17], present topic was selected for investigation. However, latex based termite formulations were prepared by using different additives which acted as synergists with the natural latex obtained from Calotropis procera. These newly designed and prepared latex based formulations were used in various bioassays in laboratory and in field experiments to control termite infestation caused by Indian white termite, Odontotermes obesus Rambur (Isoptera: Odontotermitidae). For this purpose, wood seasoning, spray, tag binding, soil treatments were done to evaluate the insecticidal and repellent potential of above formulations.

\section{MATERIALS AND METHODS}

\subsection{Insect Collection}

Termite $O$. obesus were collected from infested logs found at the University of Gorakhpur U. P. India and near by forest area of Eastern Uttar Pradesh, India. Termites removed from plant biomass and logs were maintained in glass jars ("height-24", "diameter 10") in complete dark conditions at $28^{\circ} \mathrm{C} \pm 2^{\circ} \mathrm{C}, 75 \pm 5 \mathrm{RH}$. Termites were fed on green leaves.

\subsection{Collection of Plant Latex}

Plant latex was collected from Calotropis procera (Madar) located in the botanical garden of D. D. U.
Gorakhpur University, Gorakhpur, India and it peripheral areas. Plant species was identified by applying standard taxonomic key specially by observing inflorescence and family formula with the help of a taxonomic expert. Latex was obtained from various plant parts such as stem, flower buds and unripe fruits in separate aseptic glass vessels. From stem, latex was collected by tapping method at a fixed time interval [18]. For this purpose, sharp incisions were be made on tree trunk to open the latex vessels situated in the bark or fruits were used to cut open from its top then slightly squeezed to collect unconjugated in sterile plastic vessels. It was stored at $-20^{\circ} \mathrm{C}$ until used, but mostly fresh latex samples were lyophilized and used for extraction/fractionation proposes.

\subsection{Extraction/Fractionation of Plant Latex}

Collected plant latex samples were lyophilized and powdered in vacuum in cold. Lyophilized latex was extracted with different solvents by changing the polarity. Active fractions from the latex were portioned between different solvents on the basis of their polarity. For better fractionation, solvent extraction was performed by using polar and non-polar solvents. Mostly portioning was done between hexane and aqueous methanol, petroleum ether and chloroform. Further, a portion of dried latex was extracted with distilled water, $1.5 \%$ acetic acid, $1.5 \%$ Sodium bicarbonate and $1.5 \%$ sulphuric acid and diethyl ether to separate various fractions by following the method of Steven, McCay and Paul Mahlberg [19]. Extracts were allowed to evaporate in a SpeedVac vacuum concentrators to get residue. It was dried and weighed and re-dissolved in known volume of different solvents. Dissolved residues were stored in cold at $4^{\circ} \mathrm{C}$ for experimental purpose.

\subsection{Toxicity Bioassay}

For evaluation of dose response relationship of different latex extracts, different doses (w/v), i.e. 0.5, 1.0, 2.0, $4.0,8.0,16$ and $32 \mu \mathrm{g}$ of different extracts were loaded on separate Whatmann paper strips $\left(1 \times 1 \mathrm{~cm}^{2}\right)$ and air dried to remove the solvent. These pre-coated solvent free strips were placed in the center of separate Petri dishes (42 mm diameter) as tests and uncoated as control. Twenty worker termites were released in the Petri dish to observe the mortality. After setting the experiment, green leaves were provided as food for both tests and control insects and containers were covered with black paper sheets. Mortality was recorded on the basis of dead and living termites and observations were made in triplicate for each extract and pure compounds up to $24 \mathrm{~h}$. Insects were treated as dead when become immobile and have shown no further activity to the external stimuli. The 
$\mathrm{LD}_{50}$ after $24 \mathrm{~h}$ of exposure to each was calculated by using Probit analysis tested using the method of Finney [20].

\subsection{Repellency Bioassay}

Repellent responses were observed in a glass Y-tube olfactometer by using serial concentrations $0.001,0.002$, $0.004,0.008,0.016$ and $0.032 \mu \mathrm{g}$ of different crude latex/fractions/formulations loaded on separate Whatmann paper strips $\left(1 \times 1 \mathrm{~cm}^{2}\right)$ and air dried to remove the solvent. These pre-coated solvent free strips were placed in right arm of Y-tube olfactometer (16 mm diameter $\times 90$ $\mathrm{cm}$ length) as tests while similar strips uncoated were placed in left arm as control. Twenty worker termites were released inside the opposite tri-arm to observe the repellent activity. After introduction of termites tube openings were closed by Teflon tape and number of termites oriented to towards uncoated strips or non-scented area were counted as repelled. Individuals that did not enter at least one of the arms were scored as unresponsive. Tests were conducted for $18 \mathrm{~h}$ at $27^{\circ} \mathrm{C}$ temperature. Same tests were conducted after reversing the arms to test directional bias. $\mathrm{A} \mathrm{Chi}^{2}$ test was used to compare the number of termites responding to the olfaction generated by $C$. procera active fractions. Number of repelled termites in presence of each latex extract were counted after $30 \mathrm{~min}$ of treatment with five different concentrations $(1.0,2.0,4.0,8.0$ and $16.0 \mu \mathrm{g} / \mathrm{gm})$ of each latex extract were used. The $\mathrm{ED}_{50}$ values that repelled $50 \%$ of termite population were calculated.

\section{FIELD EXPERIMENTS}

\subsection{Thread Binding Assay}

For control of termite infestation in garden plants presoaked cotton threads were tagged around the tree trunks at a height of 5 - 6 feet above the ground. For this purpose threads were soaked in Calotropis procera aqueous extract for $24 \mathrm{~h}$ and dried in shade. Early age saplings of Tectona grandis (5-year-old) trees in 8 different rows each having 24 plants were selected and tagged with the cotton threads and sprayed regularly at 15 days interval with same extract. In controls, the uncoated threads were tagged at similar height without coating any active fraction on threads. Separate rows were chosen for spray, thread binding and both.

\subsection{Wood Seasoning}

For evaluation of termiticidal action of plant latexes against termites six solid wood sticks of Tectona grandis each having 3 feet length were seasoned with three different concentrations of plant latex based formulations as CPLT 1, CPLT 2 and CPLT 3 separately . Anti-termite mixture or tincture was prepared by mixing different ingredients (60 gm Calotropis procera latex dried, $15 \mathrm{ml}$ coconut oil, $15 \mathrm{ml}$ terpene oil, $15 \mathrm{ml}$ glycerol and $15 \mathrm{gm}$ elemental sulphur in 15 liter water). In CPLT 2 and CPLT 3 mixtures Calotropis procera latex powder was mixed $45 \mathrm{gm}$ and $30 \mathrm{gm}$ while the rest of the ingredients were the same. CPLT I 2 was made by addition of $0.2 \%$ iodine to the $60 \mathrm{gm}$ Calotropis procera latex. For seasoning wood sticks were immersed in the anti-termite mixtures separately for 24 hours, then, dried for $12 \mathrm{~h}$ and planted inside soil in separate pits of 2.75 feet in depth at a distance of 3 feet. Similarly six control wood sticks were also used which were unseasoned with out any treatment. After 30 days interval each one of control and test wood stick was dug out for evaluation of anti-termite activity. $\%$ weight loss and \% infestation, exposure period and concentration of ingredients were considered for determination of anti-termite activity in wood sticks in garden soil. Experiments were run up to 180 days and wood sticks were marked with colored marker for corresponding control. Five different controls also were set for comparison, each one of them are CPLT oil, malathion, fipronil, thiomethoxam, and no treatment (negative control).

\subsection{Seed Germination, Plant Viability and Yield Indices}

Chickpea (Cicer arietinum) or Bengal gram or Kala Chana or Desi chana in Hindi, is a grown as a cash crop in Western India is a source of soil organic matter which also support edaphic biodiversity due to biological nitrogen made available by the nitrogen fixtures. Crop attracts large number of termites, which infest it from early stage to green seedling stage. The certified seeds were purchased from U. P. Seed Corporation Limited, and agronomic planting method was used by direct sowing sandy loam in texture, normal in reaction $(\mathrm{pH} \mathrm{7.8)}$ and EC of soil is $0.21 \mathrm{dsm}^{-1}$. The soil tested low in organic carbon ( 0.39 percent), organic matter ( 0.68 percent $)$ and available nitrogen $\left(178 \mathrm{~kg} \mathrm{ha}^{-1}\right)$ and medium in available phosphorus $\left(21.4 \mathrm{~kg} \mathrm{ha}^{-1}\right)$ and high in potassium $(350 \mathrm{~kg}$ $\left.\mathrm{ha}^{-1}\right)$. The experiment was replicated thrice in split plot design of $3.5 \times 3.5 \mathrm{~m}$ area for each test and control. Treatments include seed treatments by dip method overnight, spray and soil baits, prepared by adding the tested latex substances with bran, floor and cellulose paper. Round pills of $3.4 \mathrm{~mm}$ in diameter were made and posted underneath the soil by mulching and surfacing of the soil. Recommended cultural practices except for treatments under study were followed throughout the crop growth period.

\section{STATISTICAL ANALYSIS}

Standard deviations chi-square, t-significance, correla- 
tion, and ANOVA were calculated from the means of two replicate using three equal sub samples from each replicate by using method of Sokal and Rohfl [21]. In the experiments analysis of variance (ANOVA) was done whenever two means were obtained at a multiple test range and $\mathrm{p}<0.05$ probability level. The $\mathrm{LD}_{50}$ after 24 hrs of exposure were calculated by applying POLO program [22].

\section{RESULTS}

Toxic and repellent responses of various latex fractions, crude latex and its various combinatorial formulations were applied against Indian white termite $O$. obesus in the crop field and laboratory. For evaluation of toxicity and latex generated effects, insects were treated with increasing dose of various latex fractions, crude latex and its various combinatorial formulations separately. The mortality rate was found dose and time dependent as it was found to be increase with an increase in dose and exposure period. The $\mathrm{LD}_{50}$ values for different latex fractions of $24 \mathrm{~h}$ are given in Table 1. Solvent extracts have shown $\mathrm{LD}_{50}$ in a range of 5.0 - $17.613 \mu \mathrm{g} / \mathrm{mg}$ while combined mixtures of Calotropis procera have shown synergistic activity against termites and caused comparably high mortality with $\mathrm{LD}_{50} 1.987-6.016 \mu \mathrm{g} / \mathrm{mg}$ (Table 1).

Among all the fractions, methanolic fraction has shown highest toxicity in comparison to other fractions. It has shown very high anti-termite potential against $O$. obesus with an $\mathrm{LD}_{50}$ value of $5.060 \mu \mathrm{g} / \mathrm{mg}$ (Table 1). Among the combinatorial formulations CPLT + oil (1:1) have shown significantly much higher toxicity to the $O$. obesus as the LD 50 obtained was the lowest one, i.e.
$1.987 \mu \mathrm{g} / \mathrm{mg}$ (Table 1). It is highly noticeable that $\mathrm{Ca}$ lotropis procera fractions in termites remain active for longer duration and cause high lethality. The index of toxicity estimation indicates that the mean value was with in the limit at all probabilities $(90 \%, 95 \%$ and $99 \%)$ as it is less than 0.05 values of t-ratio. Besides this, regression was also found significant. The steep slope values indicate that even small increase in the dose cause high mortality. Values of the heterogeneity less than 1.0 denotes that in the replicate test of random sample, the dose response time would fall with in 95\% confidence limit and thus the model fits the data adequately (Table 1).

In olfactometry tests, $C$. procera latex solvent fractions have shown significant repellency at a very low dose $0.010-0.320 \mu \mathrm{g} / \mathrm{mg}$. Interestingly, solvent fractions have repelled mean number of insects 12.125 while 11.75 mean numbers of insects were repelled by crude latex in olfactometer. $\mathrm{ED}_{50}$ values obtained in crude latex was $0.121 \mu \mathrm{g} / \mathrm{mg}$ body weights while combinatorial formulations has shown $\mathrm{ED}_{50}$ in between 0.015 - 0.036 $\mu \mathrm{g} / \mathrm{mg}$ (Table 2). Statistical analysis of repelled and unrepelled termites gave a low Chi-square value $\left(X^{2}\right.$ value $=0.890)$ which is an indicator of independence of repellent action in selected termite groups. It shows actual ranges and expected ranges were quite independent and concentration and anti-termite formulations presented to termites were key factors in repellency in tests and comparison to control. In other experiments in which pre soaked cotton threads impregnated with Calotropis procera, crude latex were tagged around tree trunks of Tectona grandis gave similar results and justify the toxicity and repellent action of latex based formulations in ran-

Table 1. $\mathrm{LD}_{50}$ values obtained in different fractions of $C$. procera latex and its various combinatorial formulations against Indian white termite, Odontotermes obesus.

\begin{tabular}{lcccccccc}
\hline \multicolumn{1}{c}{ Extracts } & $\mathrm{hr}$ & $\begin{array}{c}\mathrm{LD}_{50}(\mu \mathrm{g} / \mathrm{gm}) \\
(\mathrm{p}<0.05)\end{array}$ & $\mathrm{LCL}$ & $\mathrm{UCL}$ & t-ratio & Slope & Heterogeneity & Chi-test \\
\hline Crude latex & 24 & 7.578 & 6.282 & 9.059 & 5.560 & 2.318 & 0.633 & 3.797 \\
Acetone Fr. & 24 & 17.613 & 15.644 & 19.647 & 6.101 & 4.140 & 0.130 & 0.649 \\
Petroleum ether Fr. & 24 & 5.534 & 4.493 & 6.677 & 6.718 & 2.103 & 0.629 & 4.404 \\
Methanol Fr & 24 & 5.060 & 4.229 & 5.889 & 5.865 & 3.226 & 0.572 & 2.289 \\
Chloroform Fr & 24 & 5.328 & 4.253 & 6.507 & 6.077 & 2.621 & 1.123 & 6.742 \\
Water Fr. & 24 & 7.354 & 6.231 & 8.925 & 5.825 & 2.637 & 0.712 & 3.562 \\
CPLT 1 & 24 & 3.217 & 2.742 & 3.751 & 6.142 & 3.162 & 0.760 & 3.798 \\
CPLT 2 & 24 & 4.158 & 3.412 & 4.996 & 6.237 & 2.552 & 1.059 & 7.417 \\
CPLT 3 & 24 & 6.016 & 5.046 & 7.017 & 6.016 & 2.918 & 0.841 & 4.207 \\
CPLT + Oil & 24 & 1.987 & 1.709 & 2.278 & 6.800 & 2.912 & 0.666 & 4.660 \\
CPLT-I2 & 24 & 2.512 & 2.082 & 2.941 & 5.694 & 3.115 & 0.599 & 2.398 \\
\hline
\end{tabular}

${ }^{\mathrm{a}} \mathrm{LD} 50$ values represents lethal dose that cause $50 \%$ mortality in the test insects. ${ }^{\mathrm{b}}$ LCL and UCL mean lower confidence limit and upper confidence limit respectively. ${ }^{c}$-ratio, slope-value and heterogeneity were significant at all probability levels $(90 \%, 95 \%$ \& $99 \%)$. t-ratio, difference in degree of freedom at 0.5 , 0.05 and 0.005 levels; slope-value shows the average between $\mathrm{LD}_{50}$ and $\mathrm{LD}_{80}$, from which $\mathrm{LD}_{50}$ value is calculated; and heterogeneity value, shows the effect of active fraction on both susceptible and tolerant insects among all of the treated insects. 
Table 2. Percent repellency obtained in different fractions of $C$. procera latex and its various combinatorial formulations against Indian white termite, Odontotermes obesus.

\begin{tabular}{lccccc}
\hline \multicolumn{1}{c}{ Latex/extracts } & Concentration in $\boldsymbol{\mu g}$ & Mean no. of Insects repelled & Expected no. of insect repelled & $\boldsymbol{\chi}^{\mathbf{2}}$ Value & ED $_{\mathbf{5 0}}$ \\
\hline Crude latex & $0.080-0.320$ & 11.75 & 10 & 2.871 & 0.121 \\
Acetone fraction & $0.010-0.200$ & 11.75 & 10 & 4.382 & 0.082 \\
Petroleum ether & $0.010-0.080$ & 11.50 & 10 & 1.211 & 0.041 \\
Methanol & $0.010-0.080$ & 12.125 & 10 & 6.317 & 0.052 \\
Chloroform & $0.010-0.120$ & 11.50 & 10 & 6.865 & 0.105 \\
Water & $0.080-0.320$ & 11.375 & 0 & 4.50 & 0.153 \\
CPLT 1 & $0.010-0.080$ & 14.00 & 10 & 2.455 & 0.019 \\
CPLT 2 & $0.010-0.080$ & 13.66 & 10 & 0.997 & 0.026 \\
CPLT 3 & $0.010-0.080$ & 11.16 & 10 & 10 & 7.421 \\
CPLT + Oil & $0.005-0.080$ & 11.50 & 10 & 2.682 & 0.036 \\
CPLT + I2 & $0.050-0.080$ & 10.33 & 5.304 & 0.015 \\
\hline
\end{tabular}

a. Not significant as the calculated values of $\chi^{2}$ were less than the table values at all probability levels $(90 \%, 95 \%$ and $99 \%)$. b. Significant at all probability levels $(90 \%, 95 \%$ and $99 \%)$; The data responses lines would fall with in $95 \%$ confidence limits and thus the model fits the data adequately. UCL-LCL ${ }^{*}$ Upper confidence limit and lower confidence limit.

Table 3. Termite management after employment of tag binding, spray, gully filling and latex washing on infested garden plants.

\begin{tabular}{lcccccc}
\hline \multirow{4}{*}{ Treatment } & \multicolumn{2}{c}{$\begin{array}{c}\text { Number of termites } \\
\text { Mean } \pm \text { SE }\end{array}$} & \multicolumn{2}{c}{$\begin{array}{c}\text { \% infestation } \\
\text { Mean } \pm \text { SE }\end{array}$} & \multicolumn{2}{c}{$\begin{array}{c}\text { \% inhibition in tunneling activity } \\
\text { Mean } \pm \text { SE }\end{array}$} \\
\cline { 2 - 7 } & Before Treatment & After Treatment & Before Treatment & After Treatment & Before Treatment & After Treatment \\
\hline \multirow{2}{*}{ Spray } & $25.77 \pm 0.531$ & $16.33 \pm 0.881$ & $80.83 \pm 0.945$ & $28.16 \pm 0.60$ & $50.42 \pm 0.782$ & $23.83 \pm 0.60$ \\
& $(100)$ & $(36.63)$ & $(100)$ & $(48.32)$ & $(100)$ & $(46.89)$ \\
Tag binding & $19.66 \pm 0.889$ & $10.33 \pm 0.66$ & $71.66 \pm 0.666$ & $16.5 \pm 0.428$ & $71.33 \pm 0.494$ & $10.5 \pm 0.428$ \\
& $(100)$ & $(52.54)$ & $(100)$ & $(23.04)$ & $(100)$ & $(14.72)$ \\
Spray and Tag & $21.16 \pm 0.557$ & $5.66 \pm 0.66$ & $77.0 \pm 0.577$ & $12.16 \pm 0.600$ & $33.57 \pm 0.719$ & $8.16 \pm 0.477$ \\
& $(100)$ & $(26.74)$ & $(100)$ & $(15.79)$ & $(100)$ & $(24.30)$ \\
Gully filling and latex washing & $23.33 \pm 0.714$ & $2.16 \pm 0.131$ & $64.5 \pm 0.846$ & $8.5 \pm 0.428$ & $26.0 \pm 0.577$ & $7.66 \pm 0.33$ \\
& $(100)$ & $(9.258)$ & $(100)$ & $(13.17)$ & $(100)$ & $(29.46)$ \\
\hline
\end{tabular}

Observations were made at every 15 -day time interval, ${ }^{*}$ Significant at $\mathrm{p}<0.01$ levels.

domly selected termites. By employing these pre-coated threads, termite infestation and tunneling activity were significantly decreased ( $\mathrm{p}<0.05$ and 0.01 ) (Table 3 ). However F-values obtained in these experiments have shown successful random control of termites in the groups. $\left[\mathrm{F}_{0.05}=4.10, \mathrm{~F}_{0.01}=7.56\right], \mathrm{F}$ is significant for $\mathrm{X}$ value while for $\mathrm{Y}$ values it is non-significant and Fxy = 5.38. It was also tried to adjust the values by computation for adjustment of SS for $\mathrm{Y}$ that shows the termite killing was significant $\left[\mathrm{df}=9, \mathrm{t}_{0.05}=2.26, \mathrm{t}_{0.01}=3.25\right.$ ] (Table 3). There was observed a significant decrease in mud plastering after regular spray on the infested trees as it was found and no further termite infestation was observed even after 6 months of experiment.

Besides this, calotropis procera latex based combinatorial formulations were also used in wood seasoning for the protection of wood from termite infestation. C. procera fractions have shown good termiticidal action as almost no infestation was observed in test wood sticks up to 6 months. The percent weight loss obtained was also minimized up to $3.94 \%$ after six month, while in un- treated sticks $57.82 \%$ weight was lost (Table 4). In case of CPLT + oil treatment weight loss was minimized up to $8.11 \%$ but it showed almost no termite infestation at a concentration of 1:1 of Calotropis procera latex and neem oil. Infestation was found to be decreased with increasing concentration of $C$. procera. Statistical analysis of infested and un-infested data have shown significant correlation between tests and control, as the values of correlation were found positive $(0.8765)$ in the weight loss and infestation in comparison to tests. The $\mathrm{p}$ value $<$ 0.0001 considered extremely significant that signifies that test wood sticks seasoned in latex formulations faced significantly very low termite infestation after long experimental duration.

In field experiments germinating crop plants were sprayed with various latex formulations of $C$. procera. These have shown very high protective efficacy against termite infestation. However, treatments done with CPLT 1 have shown better protection till the crop was matured approximately 165 - 170 days. It has significantly reduces crop losses up to $5.73 \%$, while in case of CPLT 2 it 
Table 4. Effect of plant latex based formulation on weight loss and infestation in disowned wood sticks planted in garden soil.

\begin{tabular}{|c|c|c|c|c|c|c|c|}
\hline Treatment & 0 Month & 1 Month & 2 Month & 3 Month & 4 Month & 5 Month & 6 Month \\
\hline \multirow{2}{*}{ Control (-) } & $583.3 \pm 4.721^{*}$ & $\begin{array}{c}519.3 \pm 2.54 \\
(10.97)^{*}\end{array}$ & $\begin{array}{c}431.6 \pm 4.75^{*} \\
(26.00)^{*}\end{array}$ & $\begin{array}{c}358.3 \pm 6.38 \\
(38.57)^{*}\end{array}$ & $\begin{array}{c}299 \pm 3.399 \\
(48.73)\end{array}$ & $\begin{array}{c}259.3 \pm 7.79 \\
(55.54)^{*}\end{array}$ & $\begin{array}{c}246.00 \pm 6.76 \\
(57.82)^{*}\end{array}$ \\
\hline & $0.00(0.00)$ & $\begin{array}{c}97.6 \pm 1.25^{* *} \\
(100)\end{array}$ & $\begin{array}{c}107.6 \pm 1.08 \\
(109.63)^{*}\end{array}$ & $\begin{array}{c}126 \pm 1.906 \\
(129.1)^{*}\end{array}$ & $\begin{array}{c}152 \pm 2.546 \\
(155.73)^{*}\end{array}$ & $\begin{array}{c}169.6 \pm 2.38 \\
(173.15)^{*}\end{array}$ & $\begin{array}{c}197 \pm 2.08 \\
(201.84)^{*}\end{array}$ \\
\hline \multirow{2}{*}{ Control (+) } & $649.3 \pm 8.64$ & $\begin{array}{c}638.3 \pm 11.39 \\
(1.69)^{*}\end{array}$ & $\begin{array}{c}611.33 \pm 3.03 \\
(5.84)^{*}\end{array}$ & $\begin{array}{c}598.06 \pm 2.91 \\
(7.90)^{*}\end{array}$ & $\begin{array}{c}580 \pm 4.56 \\
(10.67)^{*}\end{array}$ & $\begin{array}{c}563.33 \pm 9.02 \\
(13.24)^{*}\end{array}$ & $\begin{array}{c}542.00 \pm 13.25 \\
(16.52)^{*}\end{array}$ \\
\hline & $0.00(0.00)$ & $\begin{array}{c}8.50 \pm 0.866 \\
(100)\end{array}$ & $\begin{array}{c}14.25 \pm 1.37 \\
(167.64)\end{array}$ & $\begin{array}{c}16.75 \pm 1.25 \\
(197.1)\end{array}$ & $\begin{array}{c}19.5 \pm 1.30 \\
(229.41)\end{array}$ & $\begin{array}{c}21.6 \pm 1.495 \\
(254.11)\end{array}$ & $\begin{array}{c}23.75 \pm 1.21 \\
(279.41)\end{array}$ \\
\hline \multirow{2}{*}{ CPLT 1} & $680.33 \pm 8.27$ & $\begin{array}{c}671.66 \pm 3.899 \\
(1.32)^{*}\end{array}$ & $\begin{array}{c}634.0 \pm 8.49 \\
(6.77)^{*}\end{array}$ & $\begin{array}{c}613 \pm 3.03 \\
(9.86)^{*}\end{array}$ & $\begin{array}{c}607.33 \pm 5.24 \\
(10.73)^{*}\end{array}$ & $\begin{array}{c}602.66 \pm 5.624 \\
(11.41)^{*}\end{array}$ & $\begin{array}{c}594 \pm 4.75 \\
(12.68)^{*}\end{array}$ \\
\hline & $0.00(0.00)$ & $0.00(0.00)$ & $0.00(0.00)$ & $0.00(0.00)$ & $\begin{array}{c}8.25 \pm 2.481 \\
(5.42)^{*}\end{array}$ & $\begin{array}{c}13.5 \pm 0.645 \\
(7.95)^{*}\end{array}$ & $\begin{array}{c}16.13 \pm 0.65 \\
(8.18)^{*}\end{array}$ \\
\hline \multirow{2}{*}{ CPLT 2} & $733.33 \pm 8.25$ & $\begin{array}{c}727 \pm 10.87 \\
(0.863)^{*}\end{array}$ & $\begin{array}{c}690 \pm 4.189 \\
(5.90)^{*}\end{array}$ & $\begin{array}{c}678.33 \pm 4.45 \\
(7.54)^{*}\end{array}$ & $\begin{array}{c}670 \pm 3.29 \\
(8.59)^{*}\end{array}$ & $\begin{array}{c}663 \pm 5.62 \\
(9.54)^{*}\end{array}$ & $\begin{array}{c}694 \pm 3.85 \\
(5.36)^{*}\end{array}$ \\
\hline & $0.00(0.00)$ & $0.00(0.00)$ & $0.00(0.00)$ & $0.00(0.00)$ & $\begin{array}{l}5.25 \pm 0.93 \\
\quad(3.45)\end{array}$ & $\begin{array}{l}6.75 \pm 0.71 \\
\quad(3.97)\end{array}$ & $\begin{array}{c}9.71 \pm 0.625 \\
(4.92)\end{array}$ \\
\hline \multirow{2}{*}{ CPLT 3} & $753.33 \pm 4.838$ & $\begin{array}{c}748.33 \pm 5.811 \\
(0.707)^{*}\end{array}$ & $\begin{array}{c}737.33 \pm 5.62 \\
(2.12)^{*}\end{array}$ & $\begin{array}{c}731 \pm 4.18 \\
(2.96)^{*}\end{array}$ & $\begin{array}{c}729 \pm 5.43 \\
(3.187)^{*}\end{array}$ & $\begin{array}{c}725 \pm 2.82 \\
(3.76)^{*}\end{array}$ & $\begin{array}{c}723.60 \pm 5.70 \\
(3.94)^{*}\end{array}$ \\
\hline & $0.00(0.00)$ & $0.00(0.00)$ & $0.00(0.00)$ & $0.00(0.00)$ & $0.00(0.00)$ & $0.00(0.00)$ & $0.00(0.00)$ \\
\hline \multirow{2}{*}{ CPLT + oil } & $670 \pm 8.77$ & $\begin{array}{l}\text { 656. } \pm 10.23 \\
(2.08)^{*}\end{array}$ & $\begin{array}{c}646.33 \pm 2.68 \\
(3.53)^{*}\end{array}$ & $\begin{array}{c}634 \pm 3.741 \\
(5.37)^{*}\end{array}$ & $\begin{array}{c}624.33 \pm 3.76 \\
(6.81)^{*}\end{array}$ & $\begin{array}{c}618 \pm 2.15 \\
(7.76)^{*}\end{array}$ & $\begin{array}{c}615.66 \pm 7.81 \\
(8.11)^{*}\end{array}$ \\
\hline & $0.00(0.00)$ & $0.00(0.00)$ & $0.00(0.00)$ & $0.00(0.00)$ & $0.00(0.00)$ & $0.00(0.00)$ & $0.00(0.00)$ \\
\hline
\end{tabular}

*Values in bracket depict per cent weight loss represented in grams; ${ }^{+}$Values in brackets depict per cent weight loss and per cent termite infestation; $\%$ Wt loss is mean of weight loss obtained in six wood sticks planted in soil after seasoning. It is represented in grams.

Table 5. Effect of pant latex based formulation on protection of seed germination and plant loss due to termite infestation.

\begin{tabular}{cccccccc}
\hline & 15 days & 1 Month & 2 Month & 3 Month & 4 Month & 5 Month & 6 Month \\
\hline CPLT 1 & $136.21 \pm 1.15^{*}$ & $135.6 \pm 0.881$ & $134.8 \pm 0.948$ & $134.6 \pm 0.66$ & $132.96 \pm 1.52$ & $129.5 \pm 1.08$ & $128.4 \pm 1.19$ \\
& $000(0.00)$ & $(0.440)$ & $(1.035)$ & $(1.18)$ & $(2.37)$ & $(4.91)$ & $(5.73)$ \\
CPLT 2 & $138.6 \pm 1.20$ & $135.0 \pm 1.15$ & $133.6 \pm 1.85$ & $132.6 \pm 1.20$ & $131.0 \pm 1.15$ & $130.3 \pm 0.881$ & $129.66 \pm 0.881$ \\
& $0.00(0.00)$ & $(2.59)^{* *}$ & $(3.607)^{* *}$ & $(4.329)^{* *}$ & $(5.48)$ & $(5.98)$ & $(6.45)$ \\
CPLT 3 & $142.6 \pm 0.881$ & $141 \pm 0.577$ & $138.56 \pm 4.33^{* *}$ & $136.4 \pm 1.01$ & $134.33 \pm 0.881$ & $132.6 \pm 1.20$ & $131.17 \pm 0.460$ \\
& $000(0.00)^{*}$ & $(1.12)$ & $(2.83)$ & $(4.347)$ & $(5.799)$ & $(7.01)$ & $(8.015)$ \\
CPLT 3 & $136.21 \pm 1.15$ & $135.6 \pm 0.881$ & $134.8 \pm 0.948$ & $134.6 \pm 0.66$ & $132.96 \pm 1.52$ & $129.5 \pm 1.08$ & $128.4 \pm 1.19$ \\
& $000(0.00)$ & $(0.440)$ & $(1.035)$ & $(1.18)$ & $(2.37)$ & $(4.91)$ & $(5.73)$ \\
CPLT oil & $139 \pm 1.03$ & $138.45 \pm 1.88$ & $135.52 \pm 1.21$ & $135.34 \pm 1.49$ & $134.53 \pm 1.07$ & $134.50 \pm 0.875$ & $134.4 \pm 1.20$ \\
& $000(0.00)$ & $(0.395)$ & $(2.503)$ & $(2.63)$ & $(3.21)$ & $(3.237)$ & $(3.30)$ \\
Soil baits & $137.16 \pm 1.23$ & $135.71 \pm 1.43$ & $133.83 \pm 1.12$ & $132.16 \pm 0.874$ & $131.50 \pm 0.763$ & $129.83 \pm 5.80$ & $128.33 \pm 0.494$ \\
& $000(0.00)$ & $(1.05)$ & $(2.42)$ & $(3.645)$ & $(4.12)$ & $(5.80)$ & $(0.494)$ \\
Control & $141.83 \pm 1.12$ & $138.6 \pm 1.19$ & $66.83 \pm 0.972$ & $46.50 \pm 1.31$ & $39.16 \pm 0.849$ & $35.8 \pm 1.12$ & $31.03 \pm 0.816$ \\
& $000(0.00)$ & $(23.85)$ & $(52.88)$ & $(67.21)$ & $(72.38)$ & $(74.75)$ & $(78.12)$ \\
\hline
\end{tabular}

${ }^{*}$ Seed treatment was done for $24 \mathrm{hrs}$ by using different combinatorial formulations of latex before showing. ${ }^{* *}$ Plant loss was noted in $2.5 \times 2.5 \mathrm{~m}{ }^{2}$ plot size based on available germinating and growing plants regularly at 10 days.

was $6.45 \%$, in case of CPLT 3 it was approximately $8.01 \%$ (Table 5). When both latex seed treatments and its spray were applied it has shown massive protection against termites but provided somewhat lesser yield in comparison to others due to repellent action of neem oil to the pollinating insects. In such treatments, termite infestation was least observed. In controls, where no treatment was applied, crop losses were very high and exceeded up to $78.12 \%$ (Table 5). Statistical analysis of treated and untreated seeds, gave a negative correlation $\mathrm{r}$ $=-3780$ and $p$ value 0.0230 that considered significant.
The data analysis shows that cause of crop loss is not only due to termite infestation but some other behavioral or ecological factors are also responsible for crop losses. As in field experiments crop losses were increased with time, rise in temperature and humidity (data not presented). Negative correlation also indicates non-linear relationship of tested methods as the primary cause of termite control is toxic action of latex formulations but still secondary factors other than chemical control also help in suppression of termite population in crop fields. In the beginning, worker termites initiated destruction of 
sprouting seeds and growing plummules between day 10 - 15 , later on it was led to foliage damage up to 120 days, then infested flowering and unripe seed damage by workers and soldiers. Primary infestation was observed just after germination of seedlings, it was mainly done by dwelling soldiers and worker termites of $O$. obesus but it was rated very high between 90 - 120 days in controls in comparison to treatments done.

Plant latex based formulations have maintained the termite infestation very low that has lead to significant increase in crop yield. In field experiments when seed treatments and spray both have applied yield was very high in comparison to control in which no treatment was done. Moreover, soil baits were found more effective in crop field which successfully check the termite infestation by systemic activity. Furthermore, these have protected the plants and maintained the higher crop yield, i.e. $522.8 \pm 3.58 \mathrm{gm} / \mathrm{m}^{2}$ (Table 6) when two sprays were allowed in the same treatments. Similarly, CPLT 1 and CPLT + oil treatments have shown significantly higher crop yield $460.16 \pm 2.35$ and $423 \pm 3.80 \mathrm{gm} / \mathrm{m}^{2}$, respectively (Table 6). Spray was not found much successful in comparison to mixed methods used and it has given comparatively low yield which was obtained between 238 - $413 \mathrm{gm} / \mathrm{m}^{2}$ (Table 6). Statistical analysis of different treatments in control shows yield differences as F-values obtained were not significantly different $(\mathrm{F}=$ 0.727). Massive protection in early stage of seed germination was due to systemic action of plant latex based formulations, later on infestation was controlled by spraying the same formulations on plant foliages i.e. contact insecticidal activity. It has imposed repellent and anti-feedant activity in termites.

\section{DISCUSSION}

In the present study, plant latex based formulations have shown a significant anti-termite efficacy against Odontotermes obesus in garden saplings and crop field. In toxicity bioassays crude latex, latex fractions and its various combinatorial formulations have shown very high lethality in termites, which is proved by very low LD 50 values obtained. Further, the addition of certain additives to the latex has improved the termiticidal potential and showed synergistic activity. LD 50 values obtained in toxicity bioassays were found in a range of 1.987 - $17.613 \mu \mathrm{g} / \mathrm{gm}$ (Table 1). It is highly noticeable that Calotropis procera fractions in termites remain active for longer duration and cause high lethality. The index of toxicity estimation indicates that the mean value was within the limit at all probabilities $(90 \%, 95 \%$ and $99 \%$ ) as it is less than 0.05 values of t-ratio. Besides this, regression was also found significant. The steep slope values indicate that even a small increase in the dose causes high mortality. Values of the heterogeneity less than 1.0 denotes that in the replicate test of random sample, the dose response time would fall with in 95\% confidence limit and thus the model fits the data adequately. Analyses of experimental data clear that Calotropis procera latex contains highly toxic components which display high toxicity that is dose and time dependent. In addition, latex based formulations have shown deleterious effects on insects like anti-feedant, growth and reproductive inhibitory activities [7]. In the previous studies $C$. procera latex also showed toxic effects against Culex quinquefasciatus [11], Sarcophaga haemorrhoidalis [12] and Musca domestica [13,23], Anopheles stephensi [24] and showed inhibition of gonotrophic cycles [4], oviposition [25], egg hatching and larval development in Aedes aegypti [15]. Similarly, latexes from Euphorbia spledens var. (hislopii: Euphorbiaceae) effect post embryonic development of Megaselia sclaleris (phoridae). Latexes from Asclepias humistrata (sandhill milkweed) [26], Calotropis procera and Ficus racemosa have shown larvicidal activity [27], Parahancornia ampa (Apocynaceae), latex shows effect on post embryonic development of blowfly Chrysomya megacephala (Diptera: Calliphoridae) [28]. Similar anti-termite potential was observed in (Tung tree) Aleurites fordii extracts against Reticuletermes flavipes [29].

This insecticidal activity in plant latex is due to presence of alkaloids like nicotine, anabasine, methyl ana-

Table 6. Effect of Plant latex based formulation on yield of chickpea (Cicer arietinum) a legume of the family Fabaceae.

\begin{tabular}{cccc}
\hline Latex formulation & Seed treatment Yield in gm $/ \mathrm{m}^{2}$ & Seed treatment and spray Yield in $\mathrm{gm} / \mathrm{m}^{2}$ & Spray only Yield in gm/ ${ }^{2}$ \\
\hline CPLT 1 & $424.66 \pm 2.96(12.00)^{*}$ & $460.16 \pm 2.35(13.02)$ & $404.66 \pm 1.25(11.45)^{* *}$ \\
CPLT 2 & $378.33 \pm 3.24(10.70)$ & $409.66 \pm 3.61(11.59)^{*}$ & $358.16 \pm 2.08(10.13)$ \\
CPLT 3 & $327.33 \pm 1.52(9.26)$ & $435.16 \pm 1.74(12.31)$ & $238.00 \pm 1.39(6.37)$ \\
CPLT oil & $385 \pm 2.479(10.93)$ & $423.16 \pm 3.80(11.97)$ & $413.33 \pm 1.80(11.69)$ \\
Soil baits & $449.66 \pm 3.41(12.72)^{*}$ & $522.8 \pm 3.58(14.79)^{*}$ & $409.16 \pm 2.05(11.58)^{*}$ \\
Control & $35.33 \pm 3.47$ (no treatment) & $35.33 \pm 3.47$ (no treatment) & $21.0 \pm 1.224$ (no treatment) \\
\hline
\end{tabular}

${ }^{*}$ Seed treatment was done for $24 \mathrm{hrs}$ by using different combinatorial formulations of latex before sowing; ${ }^{* *}$ Spray was applied on the crop at an interval 20 days, \#In brackets yield is reported in folds or in times in comparison to controls. 
basine and lupinine [8], glycosidase inhibitors 1,4-dideoxy-1,4-imino-d-arabinitol (d-AB 1) and 1-deoxynojirimycin (DNJ) [8]. Similarly, cysteine proteases occur in latex of papaya (Carica papaya) and wild fig (Ficusvirgata) were found highly toxic to caterpillars of herbivorous insects [9]. Similarly, few natural products such as sugar mimic alkaloids [30,31] flavonoids [32,33], sesquiterpenes [34], triterpenes [35] and thiophenes [36], lectins [37,38], latex proteins [39], acetogenins [40] and other botanicals $[8,41]$ isolated from different plants species were found active against silk worm, Bombyx mori and termites [42]. Similarly latex chitinases [43], glycosidase inhibitors [44] and few secondary metabolites of plant origin show strong insecticidal properties [10]. Moreover, cysteine proteases, profilins and chitin-related proteins/chitinases [45] act as catalytic enzymes [46] and provide defense against phytopathogenic fungi and other bacterial infections $[47,48]$. These are insecticidal in nature and inhibit feeding, egg hatching, larval development and oviposition [49] and play an important role in plant-insect interactions [10]. Due to presence of these allergens [50] and enzymatic proteins [47], plant latex is considered analogous to animal venom and serves as defense material against herbivorous insects [44]. Plant latex from Euphorbia milii also showes molluscicidal activity and kill intermediate host Biomphalaria spp., of the human liver parasite Schistosoma mansoni. It contains Milin, a serine protease (up to $0.1 \mathrm{mg} / \mathrm{l}$ ), which significantly reduced the growth and feeding activity in snails [51]. In addition, there are so many plant species belong to different families that secrete latexes having diverse phytochemicals may possess very high insecticidal potential against many insect pests [8-10]. Moreover, plant products show both toxic and repellent activity against many insect pests [52].

Furthermore, latex generated deleterious effects in insects may be due to presence of $\alpha$-amylase inhibitors [53], $N$-acetyl- $\beta$-d-glucosaminase [54], flavonoids [55] and different types of lectins [56]. As it is already reported that laticifer fluids from Calatropis procera contain endogenous soluble proteins which are enzymatic in nature [57] and show proteolytic $[49,58]$ and insecticidal activity [49], these proteins mainly proteases found in different plant latexes [46,59] seem to be associated with insecticidal activity [60,57] and play a defensive role in plants [61] similar to lectin molecules [56]. C. procera latex also contains Kunitz-type trypsin inhibitors [62] which inhibit feeding in caterpillars by disrupting peritrophic matrix [63]. Similarly, class II chitinases and papain occurring in Carica papaya latex also play a defensive role against herbivorous insects [61] and deter them from feeding by making the food unpalatable to insects [60]. Thus, proteins, enzymes and allergens protect plants from herbivorous insect attack [64,65], but it is still unclear that repellent activity in plant latexes is due to presence of proteins or volatile substances occur in latex fluid [66]. As literature reveals, plant latexes contain different chemical components which show high anti-feedant, effects on herbivorous insects, when treated with different doses [67] in artificial diets [68]. These candidate molecules which exhibit repellency are monoterpenes, alkaloids, phenolic glycosides, [6] and 2-tridecanone [67]. However, in the present study when fractionated latex samples were used, its toxicity remained intact with the fractions and showed higher insecticidal activity in Odontotermes obesus. It is due to presence of soluble components in C. procera latexes, but precipitated substance did not show any deterrent effect on insects $[68,69]$. Thus, deterrent activity may be a consequence of a repellent effect, which is certainly operated by some soluble and non-volatile substances from latexes. There is another possibility that insecticidal activity might be associated with the carbohydrate-binding catalytic protein or may be a terpene conjugate in latex.

In addition, sub-lethal concentration (w/v) of latex fractions and different combinatorial formulations have shown significant $(\mathrm{p}<0.05)$ repellent activity at a very low dose with an $\mathrm{ED}_{50}$ ranged between $0.008-0.121$ $\mu \mathrm{g} / \mathrm{gm}$ (Table 2). Interestingly, solvent fractions have repelled mean number of insects 12.125 while 11.75 mean numbers of insects were repelled by crude latex in olfactometer. $\mathrm{ED}_{50}$ values obtained in crude latex were $0.121 \mu \mathrm{g} / \mathrm{mg}$ body weights while combinatorial formulations have shown $\mathrm{ED}_{50}$ in between $0.015-0.036 \mu \mathrm{g} / \mathrm{mg}$ (Table 2). Statistical analysis of repelled and un-repelled termites gave a low Chi-square value $\left(X^{2}\right.$ value $\left.=0.890\right)$ which is an indicator of independence of repellent action in selected termite groups. It shows actual ranges and expected ranges were quite independent and concentration and anti-termite formulations presented to termites were key factors in repellency in tests and comparison in control. Further, application of pre soaked cotton threads impregnated with Calotropis procera crude latex for tagging around tree trunks generated justifiable toxicity and repellent action in randomly selected termite population after treatment. However, employment of these precoated threads significantly decreased $(\mathrm{p}<0.05$ and 0.01$)$ infestation rate and tunneling activity in Odontotermes obesus (Table 3). However, F-values obtained indicate successful random control of termites in the groups. $\left[\mathrm{F}_{0.05}=4.10, \mathrm{~F}_{0.01}=7.56\right], \mathrm{F}$ is significant for $\mathrm{X}$ value while for $\mathrm{Y}$ values it is non-significant and Fxy $=5.38$. (Table 3). There was a significant decrease observed in mud plastering after a regular spray on the infested trees as it was found and no further termite infestation was observed even after 6 months of experiment.

When infested saplings were treated with latex formulation by applying both spray and tag binding methods, it 
has significantly reduced the number of termites $(26.74 \%), \%$ infestation $(15.79 \%)$ and tunneling activity $(24.30 \%)$ in garden (Table 3) while gully filling and latex washing gave extra decrease in number of termites $(9.258 \%), \%$ infestation $(13.17 \%)$ and tunneling activity $(29.46 \%)$ (Table 3). These have done heavy intoxication in termites, suppression of orientation, movement, feeding and tunneling behavior in termites. There was a significant decrease observed in mud plastering and tunneling behavior in termites after regular spray on the infested trees and no further termite infestation was observed even after 6 months of experiment. It shows presence of some distasteful or allergic components in Calotropis procera which are highly toxic and repellent in nature. Further, presence of these putative latex metabolites imparts deterrent activity that may be a consequence of a repellent effect, which deters large number of termites from making life surviving behavior in the foraging territory. In addition, the protective function of latex may be workable against other termite species and herbivorous insects. There is much possibility that smaller components of latex origin may be volatile in nature, act as restraint molecules and persists for longer periods after treatment in the medium.

Similar treatments of Calotropis procera latex fractions and combinatorial formulations cut down the infestation in seasoned wood sticks planted in the garden soil even after six months of treatments (Table 5). These have protected the wood weight loss up to $3.94 \%$ and no infestation was observed even after 6 months of experiments (Table 4). All such insecticidal actions of latex are due to presence of different bio-chemicals of diverse biological activity [5]. Similarly, natural amides such as nootkatone [70], valencenoid derivatives [71], imidacloprid [72] deter feeding in termites and suppress adult survival [73]. Moreover, larch wood flavonoids [74] and stilbene rich compounds such as piceid (3,4,5-trihydroxystilbene glucoside), isorhapontin (3-methoxy-3,4,5 trihydroxystilbene-3-d-glucoside) and astringin (3,3,4,5tetrahydroxystilbene-3-d-glucoside) isolated from bark of Picea glehnii also deter termites at a very low concentration 0.63 to $2.5 \mu \mathrm{mol} / \mathrm{disc}$ [75]. Similarly, 2' acetonaphthone also obstruct tunneling and feeding behavior in Formosan subterranean termite Coptotermes formosanus Shiraki at $8.33 \mathrm{mg} / \mathrm{kg}$ concentration [76] while application of Summon disks and filter paper disks coated with few chitin synthesis inhibitors, i.e. diflubenzuron, hexaflumuron and chlorfluazuron [77] controlled the aggregation, feeding and recruitment behavior in Coptotermes formosanus termites. Moreover, plumbagin, isodiospyrin and microphyllone or quinnones [78] from root extracts of Diospyros sylvatica impose significant toxic and repellent action in subterranean termite, Odontotermes obesus in filter paper disc bioassays. Similarly, in no-choice bioassays limonoids from meliaceae and rutaceae families showed strong. antifeedant activity in $R e$ ticulitermes speratus Kolbe at 510 - 1360 ppm concentration [79]. Similarly, in a filter paper based bioassay guineesine, a minor constituent isolated from Piper nigrum shows $>90 \%$ mortality in Coptotermes formosanus Shiraki at $1 \% \mathrm{wt} / \mathrm{wt}$ application [80]. It is a biodegradable environmental friendly natural product shows minimal mammalian toxicity [30]. Similarly, diterpene acids act as good anti-feedants [81] while pine resin and its derivatives, cis/trans-deiso propyl dehydroabietanol showed promising anti-termite performance [81]. Similarly, monoterpenes diterpenes sesquiterpene and hydrocarbons present in Cajput oil (Melunuca cajputi) were proved highly toxic to Coptotermes formosanus $[82,83]$.

In addition, essential oils have also shown very strong repellent and toxic activity against Formosan subterranean termite due to presence of volatile compounds [83]. Similarly essential oils such as Calocedrus formosana (Cupressaceae) effectively work against Coptotermes formosanus at very low dose $27.6 \mathrm{mg} / \mathrm{g}$ [84] while maca (Lepidium meyenii) essential oil effectively kills Coptotermes formosanus at $1 \%(\mathrm{w} / \mathrm{w})$ concentration [85]. Similarly, clove bud oil [86], patchouli oil and patchouli alcohol have shown high toxicity and repellency against termites [87]. Similarly, vetiver oil, nootkatone and disodium octaborate tetrahydrate affect termite tunneling, feeding and wood digestion by symbiont protozoa resides inside the termite gut [80]. Vetiver oil is a confined novel termiticide with reduced environmental impact for use against subterranean termites [70].

Further, in field experiments Calotropis procera latex has shown high protective efficacy in germinating crop plants against termite infestation. Thus, treatments have shown activity against termites up to crop maturation and significantly reduced crop losses up to 5.73\% (Table 5). Further, seed treatment with latex and neem oil with two sprays applied, generated massive protection against termites. In such treatments termite infestation was least observed. In controls, where no treatment was applied, crop losses were very high and exceeded up to $78.12 \%$ (Table 5). Statistical analysis of treated and untreated seeds gave a negative correlation between $r=-3780$ and $\mathrm{p}$ value 0.0230 that was considered significantly. The data analysis shows that cause of crop loss is due to not only termite infestation but some other behavioral or ecological factors which are also responsible for crop losses. As in field experiments crop losses were increased with time, rise in temperature and humidity (data were not presented). Negative correlation also indicates non-linear relationship of tested methods as the primary cause of termite control is the toxic action of latex formulations, but still secondary factors other than chemical control also help in suppression of termite population in 
crop fields. Further, latex based formulations have maintained the termite infestation very low that has led to a significant increase in crop yield. In field experiments when seed treatments and spray both have applied, yield was very high in comparison to control in which no treatment was done.

Further, for enhancing the insecticidal potential of Calotropis procera and its target specificity, elemental sulfur was mixed with latex which has shown synergistic effect on termites and successfully exploited feeding, tunneling [88] and reproductive behavior in termites [89]. These soil baits were found more effective in crop field and could check the termite infestation by systemic activity. Furthermore, these which have protected the plants and maintained the crop yield significantly higher than the controls with two sprays were allowed in the same treatments. Spray was not found much successful in comparison to mixed methods used and it has given comparatively low yield which was obtained between 238 $413 \mathrm{gm} / \mathrm{m}^{2}$ (Table 6). Statistical analysis of different treatments in control shows yield differences as F-values obtained were not significantly different $(F=0.727)$. Massive protection in early stage of seed germination was due to systemic action of plant latex based formulations, later on infestation was controlled by spraying the same formulations on plant foliages i.e. contact insecticidal activity. It has imposed repellent and anti-feedant activity in termites. It is possible that soluble fractions of latex and residual sulfur may form some new products that may enhance the toxic and repellent action against termites. Similarly, sulfonated watlle tannins alone combined with copper chloride at different concentrations and cashew nut shell liquid without or with copper chloride have successfully prevented termite attack [90]. In poison baits, a mixture of $40 \% \mathrm{CSNL}+1 \% \mathrm{CuCl}_{2}$ and $40 \% \mathrm{CNSL}+2 \% \mathrm{CuCl}_{2}$ has significantly cut down the damages done by the termites after 10 days exposure [90]. Similarly, enhancement of termiticidal activity is also observed after addition of boron [91], copper II compounds tri- and di-alkeylamine-boric acid complex [74]. These significantly reduced termite damage and infestation and are eco-friendly $[90,91]$.

As it is a well known fact that sulfur and its compounds are antimicrobial in nature, however, latex based combinatorial mixture having substantial, quantity of sulfur may affect exoskeleton of termites and show antimicrobial activity against termite gut micro-fauna. Because gut microflora is the only source of wood digesting enzymes, greater inhibition or death of microflora by latex components and sulfur may raise hunger in termites and result in higher mortality in termites like other plant derived natural products [92]. Therefore, addition of sulfur to latex based formulations and its use in any form may lead to death of termites that can control its population in crop field and in garden soil. It has doubled the protection in the seasoned woods. Hence, toxic and repellent action of latex formulations is essentially substantiated by addition of sulfur and it seems to be the reason of diminishing microbial population that helps termites in cellulose/wood digestion leading to the destruction of termites by due effects of latex components on behavior and physiology of termites. Further, gaining of extra humidity by tree bark due to pouring rain water creates a suitable substratum for growth of many fungi and bacteria. It becomes extra soft due to rain water and becomes palatable for termites and induces mud plastering and tunneling behavior in termites. If microbial population is prevented from growing on these sites by using latex based formulations, termites are forcibly prevented from mid plastering and tunneling behavior, which may be able to control termite population. Similarly, addition of Nootkatone affects wood consumption, termite survival and affects growth of flagellate symbionts [70]. Poison waits show slow release of latex formulations that prevents termites infestation for a longer period as it was observed in the field experiments. However, results obtained in present investigation show that Calotropis procera possesses enough anti-termite potential to against Indian white termite, $O$. obesus population. If used, these formulations may also provide a wide range of control against other kinds of pests. The mode of action will be both contacted and systemic that can control the termite infestation and damage. These formulations can be used in spray, or in form of poison baits or as fumigant in pure form. Hence, strong recommendations are being made to develop eco-friendly anti-termite formulation from Calotropis procera for effective control of field termites. These might be much safer, easily biodegradable in the medium, show no residual effect, cheaper and easily available in the market for farmers use. Such formulations might be environmentally more acceptable than any other synthetic pesticide and work positively in different climatic conditions against a wide range of insect pests.

\section{REFERENCES}

[1] Jitunari, F., Asakawa, F., Takeda, N., Suna, S. and Manabe, Y. (1995) Chlordane compounds and metabolite residues in termite control workers' blood. Bulletin of Environmental Contamination and Toxicology, 54, 855862. http://dx.doi.org/10.1007/BF00197970

[2] Valles, S.M. and Woodson, W.D. (2002) Insecticide susceptibility and detoxication enzyme activities among Coptotemes formosanus Shiraki workers sampled from different location in New Orleans. Comparative Biochemistry and Physiology, 131, 469-470.

[3] Hu, X.P. (2005) Valuation of efficacy and non-repellency of indoxacarb and fibronil treated soil at various concentration and thickness against two subterranean termites 
(Isoptera: Rhinotermitidea). Journal of Economic Entomology, 98, 509-517.

http://dx.doi.org/10.1603/0022-0493-98.2.509

[4] Alkofahi, A.J., Rupprecht, K., Anderson, J.E., McLaughlin, J.L. and Mikolajczak, K.L. (1987) A search for new pesticides from higher plants. Insecticides of Plant Origin, ACS Symposium Series 387, Washington DC, 24-25.

[5] Sabu, T.K. and Vinod, K.V. (2009) Population dynamics of the rubber plantation litter beetle Luprops tristis, in relation to annual cycle of foliage phenology of its host, the para rubber tree, Hevea brasiliensis. Journal of Insect Science, 9, 1-10.

[6] Hagel, J.M., Yeung E.C. and Facchini, P.J. (2008) Got milk? The secret life of laticifers. Trends in Plant Science, 13, 631-639.

http://dx.doi.org/10.1016/j.tplants.2008.09.005

[7] Carlini, C.R. and Grossi-de-Sa, M.F. (2002) Plant toxic proteins with insecticidal properties-A review on the potentialities as bioinsecticides. Toxicon, 40, 1515-1539. http://dx.doi.org/10.1016/S0041-0101(02)00240-4

[8] Sukumar, K., Perich, M.J. and Boobar, L.R. (1991) Botanical derivatives in mosquito control: A review. Journal of the American Mosquito Control Association, 7, 10-37.

[9] Shaalan, E.A.S., Canyon, D., Younesc, M.W.F., AbdelWahab, H. and Mansoura A.H. (2005) A review of botanical phytochemicals with mosquitocidal potential. Environment International, 31, 1149-1166. http://dx.doi.org/10.1016/j.envint.2005.03.003

[10] Castillo, L.E., Jiménez, J.J. and Delgado, M.A. (2010) Secondary metabolites of the Annonaceae. Solanaceae and meliaceae families used as biological control of the insects. Tropical and Subtropical Agroecosystems, 12, 445-462.

[11] Giridhar, G., Deval, K., Mittal, P.K. and Vasudevan, P. (1984) Mosquito control by Calotropis procera latex. Pesticides, 18, 26-29.

[12] Moursy, L.E. (1997) Insecticidal activity of Calotropis procera extracts on the flesh fly Sarcophaga haemorrhoidalis Fallen. Journal of the Egyptian Society of Parasitology, 2, 505-514.

[13] Morsy, T.A., Rahem M.A. and Allam K.A. (2001) Control of Musca domestica third instar larvae by the latex of Calotropis procera (Family: Asclepiadaceae). Journal of the Egyptian Society of Parasitology, 31, 107-110.

[14] Singh, R.K., Mittal, P.K. and Dhiman, R.C. (2005) Laboratory study on larvicidal properties of leaf extract of Calotropis procera (Family-Asclepiadaceae) against mosquito larvae. The Journal of Communicable Diseases, 37, 109-113.

[15] Ramos, M.V., Bandeira, G.P, De Freitas, C.D.T., Nogueira, N.A.P., Alencar, N.M.N., De Sousa, P.A.S. and Carvalho, A.F.U. (2006) Latex constituents from Calotropis procera (R. Br.) display toxicity upon egg hatching and larvae of Aedes aegypti (Linn) Memórias do Instituto Oswaldo Cruz, 101, 503-510.

http://dx.doi.org/10.1590/S0074-02762006000500004

[16] Badshah, H., Farrnanullah, Z., Salihah, Z., Saljoqi, À.U.R. and Shakur, M. (2004) Toxic effects of Ak (Calotrpis procera) plant extracts against termites (Heterotermes indicola and Coptotermes heimi) isoptera: Rhinotermitidae Pakistan. Journal of Bíological Sciences, 7, 1603-1606.

[17] Singh, N. and Kumar, S. (2008) Antitermite activity of Jatropha curcas Linn. Biochemicals. Journal of Applied Sciences and Environmental Management, 12, 67-69.

[18] Buranov, A.U. and Elmuradov, B.J. (2010) Extraction and Characterization of Latex and Natural Rubber from Rubber-bearing Plants. Journal of Agricultural and Food Chemistry, 58, 734-743. http://dx.doi.org/10.1021/jf903096z

[19] McCay, S. and Mahlberg, P. (1973) Study of Antibacterial Activity and Bacteriology of Latex from Asclepias syriaca L. Antimicrobial Agents and Chemotherapy, 3, 247253.

[20] Finney, D.J. (1971) Probit analysis. 3rd Edition, Cambridge University London, Cambridge, 333.

[21] Sokal, R.R. and Rohlf, F.J. (1973) In introduction to biostatstics, W H \& Co., San Francisco.

[22] Russell, R.M, Robertso, J.L. and Savin, N.E. (1977) POLO: A new computer program for probit analysis. Bulletin of the Entomological Society of America, 23, 209-213.

[23] Begum, N., Sharma, B. and Pandey, R.S. (2010) Evaluation of insecticidal efficacy of Calotropis procera and Annona squamosa ethanol extracts against Musca domestica. Journal of Biofertilizers \& Biopesticides, 1, 101105.

[24] Shahi, M., Hanafi-Bojd, A.A., Iranshahi, M., Vatandoost, H. and Hanafi-Bojd, M. (2010) Larvicidal efficacy of latex and extract of Calotropis procera (Gentianales: Asclepiadaceae) against Culex quinquefasciatus and Anopheles stephensi (Diptera: Culicidae). Journal of Vector Borne Diseases, 47, 185-188.

[25] Singhi, M, Joshi, V., Sharma, R.C. and Sharma, K. (2004) Oviposition behaviour of Aedes aegypti in different concentrations of latex of Calotropis procera: Studies on refractory behavior and its sustenance across gonotrophic cycles. Dengue Bulletin, 28, 184-188.

[26] Obregón, W.D., Liggieri, C.S, Trejo S.A, Avilés, F.X., Vairo-Cavalli, S.E. and Priolo, N.S. (2009) Characterization of papain-like isoenzymes from latex of Asclepias curassavica by molecular biology validated by proteomic approach. Biochimie, 91, 1457-1464. http://dx.doi.org/10.1016/j.biochi.2009.07.017

[27] Abdul Rahuman, A., Venkatesan, P., Geetha, K., Gopalakrishnan, G., Bagavan, A. and Kamaraj, C. (2008) Mosquito larvicidal activity of gluanol acetate a tetracyclic triterpenes derived from Ficus racemosa Linn. Parasitology Research, 103, 333-339. http://dx.doi.org/10.1007/s00436-008-0976-6

[28] Mendonça, P.M. Lima, M.G., Albuquerque, L.R., Carvalho, M.G. and Queiroz, M.M. (2011) Effects of latex from "Amapazeiro" Parahancornia amapa (Apocynaceae) on blowfly Chrysomya megacephala (Diptera: Calliphoridae) post-embryonic development. Veterinary Parasitology, 178, 379-382.

http://dx.doi.org/10.1016/j.vetpar.2011.01.002

[29] Hutchins, R.A. (1996) Evaluation of the natural anti-ter- 
mitic properties of Aleurites fordii (Tung tree) extracts. US Patent, Patent no. 60/016,682.

[30] Hirayama, C., Konno, K., Wasano, N. and Nakamura, M., (2007) Differential effects of sugar-mimic alkaloids in mulberry latex on sugar metabolism and disaccharidases of Eri and domesticated silkworms: Enzymatic adaptation of Bombyx mori to mulberry defense. Insect Biochemistry and Molecular Biology, 37, 1348-1358.

http://dx.doi.org/10.1016/j.ibmb.2007.09.001

[31] Oppel, C.B., Dussourd, D.E. and Garimella, U. (2009) Visualizing a plant defense and insect counter play: Alkaloid distribution in Lobelia leaves trenched by a plusiine caterpillar. Journal of Chemical Ecology, 35, 625-634. http://dx.doi.org/10.1007/s10886-009-9643-3

[32] Seetharaman, T.R. (1986) Flavonoids from the leaves of Annona squamosa and Polyalthia longifolia. Fitoterapia, 57, 189-198.

[33] Boue, S.M. and Raina, A.K. (2003) Effects of plant flavonoids on fecundity, survival, and feeding of the Formosan subterranean termite. Journal of Chemical Ecology, 29, 2575-2584. http://dx.doi.org/10.1023/A:1026318203775

[34] Arihara, S., Umeyama, A. Bando, S. Imoto, S., Ono, M. and Yoshikawa, K., (2004) Three new sesquiterpenes from black heartwood of Crytomeria japonica. Chemical \& Pharmaceutical Bulletin, 52, 463-465. http://dx.doi.org/10.1248/cpb.52.463

[35] Mazoir, N., Benharref, A, Bailén, M., Reina, M. and González-Coloma, A. (2008) Bioactive triterpene derivatives from latex of two Euphorbia species. Phytochemistry, 69, 1328-1338.

http://dx.doi.org/10.1016/j.phytochem.2008.01.004

[36] Fokialakis, N., Osbrink, W.L., Mamonov, L.K., Gemejieva, N.G., Mims, A.B., Skaltsounis, A.L., Lax, A.R. and Cantrell, C.L. (2006) Antifeedant and toxicity effects on thiophenes from four Echinops spices against the Formosan subterranean termite, Coptotermes formosanus. Pest Management Science, 62, 832-838. http://dx.doi.org/10.1002/ps.1237

[37] Wititsuwannakul, R., Wititsuwannakul, D. and Sakulborirug, C. (1998) A lectin from the bark of the rubber tree (Hevea brasiliensis). Phytochemistry, 47, 183-187. http://dx.doi.org/10.1016/S0031-9422(97)00329-4

[38] Lam, K.S. and Tzi, B.N. (2011) Lectins: Production and practical applications. Applied Microbiology and Biotechnology, 89, 45-55.

http://dx.doi.org/10.1007/s00253-010-2892-9

[39] Wasano, N., Konno, K., Nakamura, M., Hirayama, C., Hattori, M. and Tateishi, K. (2009) A unique latex protein, MLX56, defends mulberry trees from insects. Phytochemistry, 70, 880-888. http://dx.doi.org/10.1016/j.phytochem.2009.04.014

[40] Rupprecht, J.K., Hui, Y.H. and McLaughlin, J.L. (1990) Annonaceous acetogenins: A review. Journal of Natural Products, 53, 237-276. http://dx.doi.org/10.1021/np50068a001

[41] Rahman, I., Gogoi, I., Dolui, A.K. and Handique, R. (2005) Toxicological study of plant extracts on the ter- mite and laboratory animals. Journal of Environmental Biology, 26, 239-241.

[42] Kinyanjui, T., Gitu, P.M. and Kamau, G.N. (2000) Potential antitermite compounds from Juniperus procera extracts. Chemosphere, 41, 1071-1014. http://dx.doi.org/10.1016/S0045-6535(99)00460-9

[43] Diaz-Perales, A., Collada, C., Blanco, C., SanchezMonge, R., Carrillo, T., Aragoncillo, C. and Salcedo, G. (1998) Class I chitinases with hevein-like domain but not class II enzymes are relevant chestnut and avocado allergens. The Journal of Allergy and Clinical Immunology, 102, 127-133. http://dx.doi.org/10.1016/S0091-6749(98)70063-6

[44] Kitajima, K., Kamei, S., Taketani, M., Yamaguchi, F., Kawai, A. and Komatsu, Y.I. (2010) Two chitinase-like proteins abundantly accumulated in latex of mulberry show insecticidal activity. BMC Biochemistry, 11, 6-11. http://dx.doi.org/10.1186/1471-2091-11-6

[45] Ding, X., Gopalakrishnan, B., Johnson, L.B., White, F.F., Wang, X., Morgan, T.D., Kramer, K.J. and Muthukrishnan, S. (1998) Insect resistance of transgenic tobacco expressing an insect chitinase gene. Transgenic Research, 7, 77-84. http://dx.doi.org/10.1023/A:1008820507262

[46] Domsalla, A. and Melzig, M.F. (2008) Occurrence and properties of proteases in plant latices. Planta Medica, 74, 699-711. http://dx.doi.org/10.1055/s-2008-1074530

[47] Yagami, T., Sato, M., Nakamura, A., Komiyama, T., Kitagawa, K., Akasawa, A. and Ikezawa, Z. (1998) Plant defense-related enzymes as latex antigens. The Journal of Allergy and Clinical Immunology, 101, 379-385. http://dx.doi.org/10.1016/S0091-6749(98)70251-9

[48] Sequira, B.J., Vital, B.J., Pohlit, A.M., Pararols, I.C. and Cauper, G.S.B. (2009) Antibacterial and antifungal activity of extracts and exudates of the Amazonian medicinal tree Himatanthus articulates (Vahl) Woodson (Common neme: Sucuba). Memórias do Instituto Oswaldo Cruz, 104, 34-39.

[49] Ramos, M.V., Pereira, D.A., Souza, D.P., Araújo, E.S., Freitas, C.D.T., Cavalheiro, M.G., Matos, M.P.V. and Carvalho, A.F.U. (2009) Potential of laticifer fluids for inhibiting Aedes aegypti larval development: Evidence for the involvement of proteolytic activity. Memórias do Instituto Oswaldo Cruz, 104, 805-812. http://dx.doi.org/10.1590/S0074-02762009000600001

[50] Yagami, T. (1998) Plant defense-related proteins as latex allergens. Bulletin of National Institute of Health Sciences, 116, 46-62.

[51] Giovanelli, A., da Silva, C.L., Medeiros, L. and de Vasconcellos, M.C. (2001) The molluscicidal activity of the latex of Euphorbia splendens var. hislopii on Melanoides tuberculata (Thiaridae), a snail associated with habitats of Biomphalaria glabrata (Planorbidae). Memórias do Instituto Oswaldo Cruz, 96, 123-125.

[52] Blaske, V.U. and Hertel, H. (2001) Repellent and toxic effects of plant extracts on subterranean termites (Isoptera: Rhinotermitidae). Journal of Economic Enotomology, 94, 1200-1208.

http://dx.doi.org/10.1603/0022-0493-94.5.1200

[53] Farias, L.R., Costa, F.T., Souza, L.A., Pelegrini, P.B., 
Grossi-de-Sá, M.F., Neto, S.M., Bloch Jr., C., Laumann, R.A., Noronha, E.F. and Franco, O.L. (2007) Isolation of a novel Carica papaya $\alpha$-amylase inhibitor with deleterious activity toward Callosobruchus maculatus. Pesticide Biochemistry and Physiology, 87, 255-260. http://dx.doi.org/10.1016/j.pestbp.2006.08.004

[54] Giordani, R., Benyahia, S., Teissere, M. and Noat, G. (1992) Purification and properties of $N$-acetyl- $\beta$-glucosaminase from Hevea brasiliensis latex. Plant Science, 84, 25-34. http://dx.doi.org/10.1016/0168-9452(92)90204-Y

[55] Salunke, B.K., Kotkar, H.M., Mendki, P.S., Upasani, S.M. and Maheshwari, V.L. (2005) Efficacy of flavanoids in controlling Callosobruchus chinensis (L.) (Coleoptera:Bruchidae), a post-harvest pest of grain legumes. Crop Protection, 24, 888-893. http://dx.doi.org/10.1016/j.cropro.2005.01.013

[56] Sadegh, A., Van Damme, E.J.M., Peumans, W.J. and Smagghe, G. (2006) Deterrent effect of plant lectins on cowpea weevil Callosobruchus maculatus (F.) oviposition. Phytochemistry, 67, 2078-2084.

http://dx.doi.org/10.1016/i.phytochem.2006.06.032

[57] Freitas, C.D.T., Oliveira, J.S., Miranda, R.A., Macedo, N.M.R., Sales, M.P., Villas-Boas, L.A. and Ramos, M.V. (2007) Enzymatic activities and protein profile of latex from Calotropis procera. Plant Physiology and Biochemistry, 45, 781-789. http://dx.doi.org/10.1016/j.plaphy.2007.07.020

[58] Freitas, C.D.T., Souza, D.P., Araújo, E.S., Cavalheiro, M.G., Oliveira, L.S. and Ramos, M.V. (2010) Anti-oxidative and proteolytic activities and protein profile of laticifer cells of Cryptostegia grandiflora, Plumeria rubra and Euphorbia tirucalli. Brazilian Journal of Plant Physiology, 22, 11-22. http://dx.doi.org/10.1590/S1677-04202010000100002

[59] Domsalla, A. and Melzing, M.F. (2008) Occurrence and properties of proteases in plant latices. Planta Medica, 74, 699-711. http://dx.doi.org/10.1055/s-2008-1074530

[60] Dubey, V.K. and Jagannadham, M.V. (2003) Procerain, a stable cysteine protease from the latex of Calotropis procera. Phytochemistry, 62, 1057-1071. http://dx.doi.org/10.1016/S0031-9422(02)00676-3

[61] Konno, K., Hirayamura, C., Tateishi, K., Tamura, Y. and Hattori, M. (2004) Papain protects papaya trees from herbivorous insects: Role of cysteine proteases in latex. The Plant Journal, 37, 370-378. http://dx.doi.org/10.1046/j.1365-313X.2003.01968.x

[62] Ramos, M.V., Grangeiro, T.B., Freire, E.A., Sales, M.P., Souza, D.P., Araújo, E.S. and Freitas, C.D.T. (2010) The defensive role of latex in plants: Detrimental effects on insects. Arthropod-Plant Interactions, 4, 57-67. http://dx.doi.org/10.1007/s11829-010-9084-5

[63] Azarkan, M., Amrani, A., Nus, M., Vandermeers, A., Zerhouni, S., Smolders, N. and Looze, Y. (1997) Carica papaya is a rich source of a class II chitinase. Phytochemistry, 48, 1319-1325.

[64] Pechan, T., Cohen, A., Williams, W.P. and Luthe, D.S. (2002) Insect feeding mobilizes a unique plant defense protease that disrupts the peritrophic matrix of caterpillars. Proceedings of the National Academy of Sciences of the
United States of America, 99, 13319-13323. http://dx.doi.org/10.1073/pnas.202224899

[65] Fiorillo, F., Palocci, C., Soro, S. and Pasqua, G. (2007) Latex lipase of Euphorbia characias L: A specific acylhydrolase with several isoforms. Plant Science, 172, 722727. http://dx.doi.org/10.1016/j.plantsci.2006.11.020

[66] Yeang, H.Y., Arif, SAM, Yusof, F. and Sunderasan, E. (2002) Allergenic proteins of natural rubber latex. Methods, 27, 32-45.

[67] Ramos, M.V., Araújo, E.S., Oliveira, R.S.B., Teixeira, F.M., Pereira, D.A., Cavalheiro, M.G., Souza, D.P., Oliveira. J.S. and de Freitas, C.D.T. (2011) Latex fluids are endowed with insect repellent activity not specifically related to their proteins or volatile substances. Brazilian Journal of Plant Physiology, 23, 57-66. http://dx.doi.org/10.1590/S1677-04202011000100008

[68] Braga, Y.F., Grangeiro, T.B., Freire, E.A., Lopes, H.L., Bezerra, J.N., Andrade-Neto, M. and Lima, M.A. (2007) Insecticidal activity of 2-tridecanone against cowpea weevil Callosobruchus maculates (Coleoptera: Bruchidae). Anais da Academia Brasileira de Ciências, 79, 3539.

[69] Ramos, M.V., Freitas, C.D.T., Stanisçuaski, F., Macedo, L.L.P., Sales, M.P., Souza, D.P. and Carlini, C.R. (2007) Performance of distinct crop pests reared on diets enriched with latex proteins from Calotropis procera: Role of laticifer proteins in plant defense. Plant Science, 173, 349-357. http://dx.doi.org/10.1016/j.plantsci.2007.06.008

[70] Zhu, B.C., Handerson, G., Chen, F., Masitrello, L. and Laine, R.A. (2001) Nootkatone is repellent for Formosan subterranean termites (Coptotermes formosanus). Journal of Chemical Ecology, 27, 523-531. http://dx.doi.org/10.1023/A:1010301308649

[71] Zhu, B.C., Henderson, G., Sauer, A.M., Yu, Y., Crowe, W. and Lanie, R.A. (2003) Structure-activity of valencenoid derivates and their repellence to the Formosan subterranean termite. Journal of Chemical Ecology, 29, 26952701.

[72] Osbrin, W.L. and Lax, A.R. (2003) Effect of imidacloprid tree treatments on the occurrence of Formosan subterranean termites, Coptotermes formosanus shiraki (Isoptera: Rhinotermitidae), in independent monitors. Journal of Economic Entomology, 96, 117-125.

http://dx.doi.org/10.1603/0022-0493-96.1.117

[73] Upadhyay, R.K., Jaiswal, G., Ahmad, S., Leena, K. and Jain, S.C. (2012) Antitermite activities of $C$. deciduas extracts and pure compounds against Indian White termite Odontotermes obesus (Isoptera: Odontotermitidae). Psyche, 2012, Article ID 820245.

[74] Chen, K., Ohmura, W., Doi, S. and Aoyama, M. (2004) Termite feeding deterrent from Japanese larch wood. Bioresource Technology, 95, 129-134. http://dx.doi.org/10.1016/j.biortech.2004.02.014

[75] Shibutani, S., Smejima, M. and Doi, S. (2004) Effects of stilbenes from bark of Picea glehnii (Sieb. Et. Zucc) and their related compounds against feeding behavior of $R e$ ticulitermes speratus. Journal of Wood Science, 50, 439444. http://dx.doi.org/10.1007/s10086-003-0583-1

[76] Ibrahim, S.A., Henderson, G., Fei, H. and Lanie, R.A. 
(2004) Survivorship, tunneling and feeding behaviors of Coptotermes formosanus (Isoptera: Rhinotermitidae) in response to 2'-acetonaphthone-treaed sand. Pest Management Science, 60, 746-754. http://dx.doi.org/10.1002/ps.852

[77] Rojas, M.G. and Morales-Ramos, J.A. (2001) Bait matrix for delivery of chitin synthesis inhibitior to the formosan subterranean termite (Isoptera: Rhinotermitidae). Journal of Economic Entomology, 94, 506-510. http://dx.doi.org/10.1603/0022-0493-94.2.506

[78] Ganapaty, S., Thomas, P.S. and Fotso, L.H. (2004) Antitermite quinines from Diospyros sylvatica. Phytochemistry, 65, 1265-1267.

http://dx.doi.org/10.1016/j.phytochem.2004.03.011

[79] Serit, M., Ishida, M., Hagiwara, N., Kim, M., Yamamoto, T. and Takahashi, S. (1992) Meliaceae and rutaceae limonoids as termite antifeedents evaluated using Reticulitermes speratus Kolbe ((Isoptera: Rhinotermitidae). Journal of Chemical Ecology, 18, 593-603. http://dx.doi.org/10.1007/BF00987822

[80] Meepagala, K.M., Osbrink, W., Mims, A.B., Lax, A.R. and Duke, S.O. (2006) Amides based on natural products against Formosan subterranean termites (Coptotermes formosanus). Natural Product Utilization Research. US Patent.

[81] Nunes, L.T., Nobre, B., Gigante, A. and Silva, M. (2004) Toxicity of pine resin derivatives to subterranean termites (Isoptera: Rhinotermitidae). Management Environoental Quality International Journal, 15, 521-528.

[82] Cornelius, M.L., Grace, J.K. and Yates, J.R. (1997) Toxicity of monoterpenoids and other natural products to the formosan subterranean termite (Isoptera: Rhinoter-mitidae). US Patents No. 1997049246.

[83] Kim, J.H., Liu, K.H., Yoon, Y., Sornnuwat, Y., Kitirattrakarn, T. and Anantachoke, C. (2006) Essential leaf oils from Melaleuca cajuputi. Traditional medicine and nutraceuticals ISHS. III WOCMAP congress on medicinal and aromatic plants. Acta Horticulturae, 6, 680.

[84] Cheng, S.S., Wu, C.L., Chang, Y.T. and Chang, S.T. (2004) Antitermitic and antifungal activities of essential oil of Calocedrus formosana leaf and its composition. Journal of Chemical Ecology, 30, 1957-1967.
[85] Tellez, M.R., Khan, I.A., Kobaisy, M., Schrader, K.K. and Dayan, F.E. (2002) Composition of essential oil of Lepidium meyenii (Walp). Phytochemistry, 61, 149-155. http://dx.doi.org/10.1016/S0031-9422(02)00208-X

[86] Park, I.K. and Shin, S.C. (2005) Fumigant activity of plant essential oils and components from garlic (Allium sativum) and clove bud (Eugenia caryophyllata) oils against the Japanese termite (Reticulitermes speratus Kolbe). Journal of Agriculture and Food Chemistry, 53, 4388-4392. http://dx.doi.org/10.1021/jf050393r

[87] Zhu, B.C., Henderson, G., Yu, Y. and Laine, R.A. (2003) Toxicity and repellency of patchouli oil and patchouli alcohol against Formosan subterranean termites Coptotermes formosanus Shiraki (Isoptera: Rhinotermitidae). Journal of Agricultural Food Chemistry, 51, 4585-4588. http://dx.doi.org/10.1021/jf0301495

[88] Su, N.Y., Ban, P.M. and Scheffrahn, R.H. (2000) Control of Coptotermes havilandi (Isopetera: Rhinotermitidae) with hexaflumuron baits and a sensor incorporated into a monitoring and baiting program. Journal of Economic Entomology, 93, 415-421. http://dx.doi.org/10.1603/0022-0493-93.2.415

[89] Cornelius, M.L. and Lax, A.R. (2005) Effects of summon preferred food source on feeding, tunneling and bait station discovery by the Formosan subterranean termite (Isoptera: Rhinotermitidae). Journal of Economic Entomology, 98, 502-508. http://dx.doi.org/10.1603/0022-0493-98.2.502

[90] Mwalongo, G.C.J., Mkayula, L.L., Mubofu, E.B. and Mwingira, B.A. (1999) Preventing termite attack: Environmentally friendly chemical combinations of cashew nut shell liquid, sulfited wattle tannin and copper (II) chloride. Green Chemistry, 35, 13-16.

[91] Grace, J.K. and Abdallay, A. (1990) Termiticidal activity of boron dusts (Isoptera: Rhinotermitidae). Journal of Applied Entomology, 109, 283-288. http://dx.doi.org/10.1111/j.1439-0418.1990.tb00052.x

[92] Meepagala, K.M., Osbrink, W., Sturtz, G. and Lax, A. (2006) Plant derived natural products exhibiting activity against Formosan subterranean termites (Coptotermes formosanus). Pest Management Science, 62, 565-570. 